\title{
Alien Monstrosity: The Practice of Technology and "Race" as Technological Construct in Star Trek: Voyager
}

Nils Jablonski

\section{(2) OpenEdition} Journals

Electronic version

URL: https://journals.openedition.org/ejas/16943

DOI: $10.4000 /$ ejas. 16943

ISSN: 1991-9336

Publisher

European Association for American Studies

Electronic reference

Nils Jablonski, "Alien Monstrosity: The Practice of Technology and "Race" as Technological Construct in Star Trek: Voyager", European journal of American studies [Online], 16-2 | 2021, Online since 13 July 2021, connection on 17 October 2022. URL: http://journals.openedition.org/ejas/16943 ; DOI: https:// doi.org/10.4000/ejas. 16943

This text was automatically generated on 17 October 2022

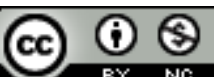

Creative Commons - Attribution-NonCommercial 4.0 International - CC BY-NC 4.0 https://creativecommons.org/licenses/by-nc/4.0/ 


\title{
Alien Monstrosity: The Practice of Technology and "Race" as Technological Construct in Star Trek: Voyager
}

\author{
Nils Jablonski
}

\section{The Star Trek Franchise and its Multi-Ethnic Universe: "Race" and Science Fiction}

1 Alongside class, gender and age, race and/or ethnicity is one of the fundamental parameters for any critical cultural analysis-and at the same time it is an elementary category in modern science fiction, especially when its stories "take place in imaginary settings that... posit possible future worlds" (Carrington 8). Science fiction (SF) is a relatively young genre that emerged, as Fredric Jameson states, "during the second half of the nineteenth century" (Jameson 284). Generally, SF deals with technological inventions and their possible impact on society. In the second half of the twentieth century this "utopian imagination" (Jameson 289) shifts more and more into space exploration. Although these SF-narratives in literature, film, and television are mostly "about close encounters with aliens," they turn out to be, in fact, "thinly veiled political metaphors of the pressing geopolitical concerns of the cold war era" (Nama 96). The socalled 'space age' of the 1960s und early 1970s marks a crucial moment in the history of popular television since one of the most successful science fiction series of all time was aired during this period-first in the United States, and later throughout the world. As Michael C. Pounds remarks, Gene Roddenberry's Star Trek (1966-1969) presents a "utopian vision:" the series depicts a future which "has found solutions to economic crisis, criminal behavior, mental illness, and physical disease" (Pounds 171).

The novelty of Roddenberry's Star Trek lies in its propagation of progressive "principles of tolerance and respect for all life-forms, however unfamiliar" (Graham 134). Elaine L. 
Graham argues that Roddenberry's approach is unusual for television at that time since Star Trek depicts "a society truly characterized by racial and cultural diversity" (134). She points out Star Trek's typically metaphorical use of "alien species" in the context of US-politics of that era; encounters with unfamiliar and unknown others "serv[e] as the fictional vehicle for themes of human diversity, conflict and reconciliation and reflect[] the preoccupation of a culture struggling to come to terms with the upheavals of the civil rights movement and the enmities of the Cold War" (Graham 134). While Graham thus concludes that the encounters with "alien humanoid species" presented in Star Trek can be seen "as extended allegories for racial and cultural pluralism" (Graham 133), Pounds argues that most "ethnic characters" in the series are mere "functionnaires," used either as "a detail to move the plot along" or as stereotypes, such as "devoted servant, vicious criminal, knife toter, high-tech mechanic, mental inferior, sexual superman, violent savage" (Pounds 172f.).

The vast majority of "extraterrestrials" in the franchise's multi-ethnic universe are "sentient beings" (Bernardi 209) belonging to humanoid species. ${ }^{1}$ These aliens are similar to humans but possess different physiologies and cultural habits and use technology differently. Since its alien characters are for the most part "anthropomorphic," the franchise continues the tradition of what Darko Suvin calls the "analogic model of SF" (29). Thus, the depictions of a multi-ethnic universe can be understood in Suvin's terms as "modern parables" (30). In this context aliens serve the purpose of representing "Otherness, particularly in reference to the difficulties and conflicts stemming from physiognomic and cultural difference" (Bernardi 218f.). Therefore, Daniel Bernardi describes the metaphorical function of aliens "as an implicit means by which human experience and likeness are imagined and fictionalized" (219). Taking into account Jameson's claim that "genuine alienness or otherness" is, in fact, "impossible and unachievable," the metaphorical use of aliens in any SF becomes apparent as "mere structural play of purely human themes and topics" (Jameson 124). Race, of course, is one of these topics: SF reflects upon this cultural category according to the genre's typical stylistic device of analogy. As Robin A. Roberts points out, race is displaced "onto aliens," thus "science fiction defamiliarizes the category" and thereby challenges common "assumptions and prejudices about race," such as whether it is "a social construct," "determined by culture," or "[f]iltered through biology" (Roberts 205).

While the multi-ethnic universe of the Star Trek franchise is populated by an infinite number of life-forms, the means of classifying these sentient non-human beings are limited: they are referred to as either species or races, without any further indication that these taxonomical orderings are connected to socio-cultural constructs such as peoples, civilizations or cultures. Despite Star Trek's indiscriminative use of both "species" and "race," there are semantic differences between them: in contrast to the term "species," which refers to animals or plants that are "capable of exchanging genes or interbreeding" (Oxford Dictionary of English), "race" is used in cultural contexts to divide human beings into groups of people "sharing the same culture, history, language, etc." (Oxford Dictionary of English)-at least purportedly. The segregating implications of "race" are stressed when they are associated with "distinct physical characteristics" (Oxford Dictionary of English). Thus, if this term is used to "divide the universality of the human species," as Etienne Balibar explains, "into exclusive transhistorical groups which are supposed to be separated by essential differences" (192), racism evolves. According to Balibar racism can therefore be understood as "a 
genuine mode of thought" that becomes a discursive practice "connecting not only words with objects, but more profoundly words with images, in order to create concepts" (200). Related to the term "race," but semantically broader and therefore frequently used as an alternative in cultural studies, the adjective "ethnic" refers to "a population subgroup (within a larger or dominant national or cultural group) with a common national or cultural tradition" (Oxford Dictionary of English); accordingly, the noun 'ethnicity' refers to "the fact or state of belonging to a social group that has a common national or cultural tradition" (Oxford Dictionary of English).

The political ambitions of the Star Trek franchise with its seven independent series lie in the depiction and reflection of "experiences and ideologies of physiognomic and cultural difference via science-fiction metaphors like aliens" (Bernardi 2010). Despite its "liberal humanist message... which advocates a future without racism, sexism, and other forms of prejudice," Star Trek of the 1960s, later referred to as "the original series,' is inherently "undermined by the inadvertent assumption of racial and cultural normativity" (Kwan 69). And like its predecessor, Star Trek: The Next Generation (19871994) still advocates "normative Whiteness" by equating "being 'human' with being European and White" (Kwan 60). This is reflected through a predominantly patriarchal structure aboard the starship U.S.S. Enterprise under the command of Captain Jean-Luc Picard and his first officer Commander William T. Riker. However, the two following sequels in the Star Trek franchise differ distinctively from the previous series by breaking the line of white male lead characters: with Benjamin Sisco, Star Trek: Deep Space Nine (1993-1999) presents an African-American commander of a space station protecting peace in a conflict between two alien races; and in Star Trek: Voyager (19952001) the burdensome task of finding a way back home to earth after stranding on the other side of the galaxy falls to a female, Captain Kathryn Janeway.

6 The three sequels to the original series embody the "Golden Age" of the Star Trek franchise: while Captain Kirk and his crew explore the galaxy in the $23^{\text {rd }}$ century, Picard, Sisco, and Janeway are pioneers in the galaxy a hundred years later. The Next Generation lays out the common ground for the 'utopian vision' of this Golden Age: the United Federation of Planets seeks peace and freedom for its human and non-human members who all share the "virtues of self-improvement, tolerance, progress and optimism"; among the various alien ethnicities of their interstellar community, differences and potential dissent fade by virtue of a "shared humanity "under the skin"” (Graham 136). The binding values of the Federation's members are, in fact, those of humanism deriving from $18^{\text {th }}$ century Earth's "Enlightenment discourse," such as "the rights of man, reason, freedom of speech, belief and movement" (Graham 141). They are upheld "as timeless and unimpeachable" (Graham 141) by Starfleet, the Federation's military-like organization whose starships are on scientific, diplomatic, and humanitarian missions. Graham concludes that Star Trek "is at heart an exploration not so much of the galaxy beyond as the contours of human identity within" because the narrated "encounters with alien civilizations invite viewers on an inward journey into the nature of subjectivity, identity, diversity and community" (132f.).

While virtually all episodes of The Next Generation present a "humanist happy ending" by restoring "the constants of human identity, stability and order" (Graham 151), Deep Space Nine and Voyager differ from this static scheme by deploying the narrative structure of serials. Although The Next Generation does present recurring characters like 
the omnipotent $Q$ and includes a few cliffhangers that span two episodes, these modes of televised narration are used much more frequently in Deep Space Nine and Voyager. From the beginning, these two series offer more complex, over-arching storylines which either cover several episodes or reintegrate peripheral events or characters from previous episodes. These narrative forms also intertwine all three series: for instance, side characters from The Next Generation, such as transporter chief Miles O'Brien and security officer Worf, become lead characters in Deep Space Nine. And Voyager begins on the very starbase where Deep Space Nine takes place. During their ongoing, homewardbound journey, Voyager's crew encounters the Borg, a hostile race of cybernetic lifeforms, first introduced as the ultimate threat to Starfleet and the Federation in The Next Generation. All of these cross-references throughout the three series show how Roddenberry's approach in the original series is still present in the sequels; their narrative schemes perpetuate, as Roddenberry says, "infinite diversity in infinite combinations" (Bernardi 211) in the depiction of a multi-ethnic universe.

In Voyager, the use of technology by alien races becomes the primary focus as the series reflects on Starfleet and the Federation's humanist values in particular and on humanity in general. As long as the use of technology conforms with Starfleet politics it can be understood to be "good," while any deviation must be considered "bad," since the use of technology then no longer serves an altruistic purpose-at least from a humanist perspective. Furthermore, these two poles determine the major paradigms underlying the depiction of alien races in the series: human vs. animal on the one hand and human vs. machine on the other. In the following, I will analyze several episodes of Voyager in order to show how such strict binary oppositions are destabilized, moving towards a more posthuman depiction of race. Indeed, race in Voyager is not simply presented as a cultural construct, but as a construct that depends on the specific depiction of the use of technology. The interdependency of technology and race in the series shows that technology and race are fundamental topoi of the SF genre.

\section{Star Trek: Voyager: The Use of Technology as (Post-)Humanist Practice}

9 Certainly, "alien humanoid species" presented in the multi-ethnic universe of the franchise are to be understood metaphorically and encounters with these races are often "extended allegories for racial and cultural pluralism" (Graham 22). Unfortunately, "ethnic representations" in all of the Star Trek series lean "heavily on the old negative stereotypes that associate ethnic characters with body-service occupations, machine operations, violent behavior, and sexual aggression" (Pounds 184). Pounds observes that the use of machines in particular and technology in general is an important aspect in the depiction of race since "Star Trek differentiates between whites and ethnics over the issue of technique and technology" (Pounds 182). Referring to Jacques Ellul, Pounds defines "technique" as the "intellectual process of conceptualizing problems" and "technology" as "the materialization of this thought process" (182). Given this difference, he comes to the conclusion that "the white male Starfleet officer is directly associated with command (technique)" whereas "the ethnic officer is only permitted control over technology" (182).

10 Pounds' observations and conclusions are undoubtedly true for the patriarchy on the U.S.S. Enterprise in The Next Generation, but Deep Space Nine and especially Voyager 
dismantle this logocentric association of "technique... with mind and technology with body" (182). If "race" is to be understood as bound up with the use of technology, Pound's differentiation between the categories "technique" and "technology" must be revisited. In Voyager the use of technology goes hand in hand with the thought processes of command (technique); in the context of my argumentation the use of technology thus always includes technique. Such a use no longer defines and sets ethnic distinctions among the Federation's officers as seen in The Next Generation, but rather it underscores the differences between humans and aliens. Therefore, the use of technology in Voyager can be considered a (post-)humanist practice, and accordingly the use of technology by aliens becomes the foil against which to reflect on the humanist values represented by Starfleet and the Federation. Consequently, race here itself can be understood as a practice of technology.

11 Such new perspectives on the use of technology in Star Trek have to be read in the broader context of posthumanism which emerges in the 1980s. These perspectives offer a critical reflection on technological developments and their impact on human life and values, such as on absolute distinctions between "humans, animals and machines, artificial and natural, 'born' and 'made"' (Graham 1f.). The whole storyline in Voyager contributes to the series' posthuman discourse. The ship's "loss of contact with Federation authority and mores, plus its need for self-reliance in a frequently hostile territory" constitute an environment "in which there are few fixed points of reference, and few permanent values" (Graham 149). Under these circumstances, any use of technology in the series can be considered an allegorical reference to "the posthuman condition" (Graham 10) because "the confidence of universal humanist percepts is beginning to disintegrate and alternative values must be exercised" (Graham 149).

In Voyager, the starship itself "as a biology/machine merger" is a metaphor for "the posthuman condition" (Haney 84). Equipped with so-called bioneural gel packs serving as circuits to increase Voyager's computed "reactions," the vessel is a "composite body" (Haney 78) blurring the lines between technology and nature. In fact, at one point some non-sentient alien entities living in space confuse the starship with a potential partner and they try to mate with Voyager (cf. Voyager S02/E04). In another episode the ship becomes ill because its gel packs have been infected with a virus (cf. Voyager S01/E15). Consequently, the repair can only be executed through the joint efforts of Voyager's chief engineer and its medical officer-the first being a female who is half Klingon and half human, the latter a computer-generated projection of artificial intelligence. As Emergency Medical Hologram (EMH) the ship's doctor is one of the major examples of the many posthuman topoi negotiated in the series. While the vessel itself erodes "the boundaries between humans, animals and machines," this character calls into question the "distinctions between the virtual and the real" (Graham 4), especially when the doctor's rights as a person are in dispute over the ownership of his fictional writings (cf. Voyager S07/E20).

13 The complexity of the series' rendition of alien races can best be illustrated through a coordinate system (cf. Fig. 1): one axis depicts a continuum of otherness between the poles of animal and machine, the other axis depicts the use of technology between hostile and peaceful. The continuum of otherness forms a horizontal axis while the vertical axis spans the difference between "good" and "bad" uses of technology according to Starfleet and the Federation's humanist values, such as individuality, equality, and freedom including tolerance and respect for others. Thus, this coordinate 
system constitutes an analytical matrix that makes it possible to describe alien races in regard to their differences to humans via both their physiognomy and habits as well as their use of technology.

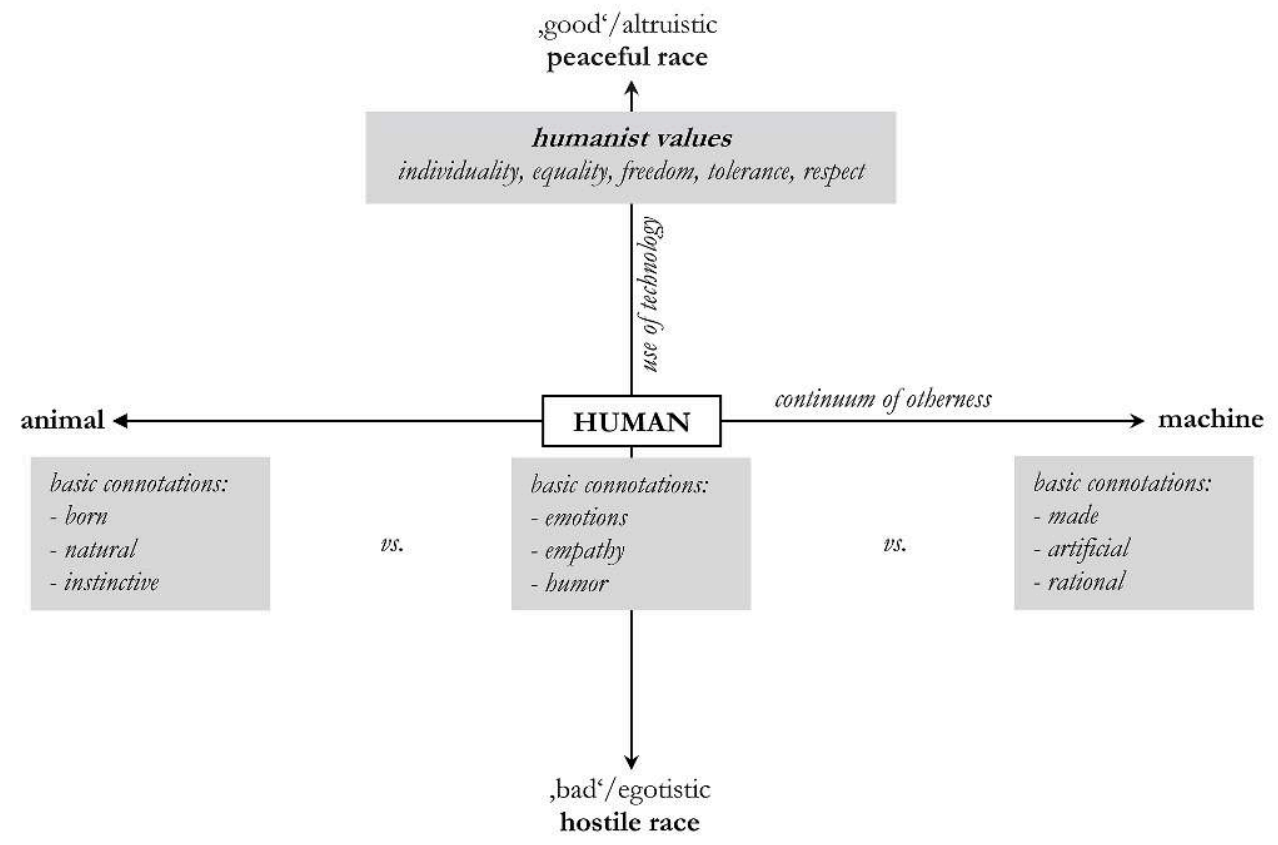

Figure 1: Analytical matrix (Nils Jablonski).

With the 'ideal' Human in the center of this coordinate system, the analytical matrix takes into account two aspects: first, that the entire Star Trek franchise "promotes an anthropocentric position... in the representation of other alterns" (Neuwirth par. 4); second, that aliens in all the Star Trek series function as metaphors that stand in for otherness. In Voyager this otherness is signified by difference of appearance. Yet, this difference is not only expressed through physiognomy but also through the specific use of technology. Therefore, on both axes the category "Human" is in the middle: on the $\mathrm{x}$-axis the poles "animal" and "machine" are distinct from each other; the first connotes "born," "natural," and "instinctive," the second "made," "artificial," and "rational." The category "Human" is situated between these poles because as cultural beings, humans are "natural" and "born," yet they do not rely solely on their instincts. On the contrary, they can willingly subordinate their behavior to "rationality," one of the major characteristics of human-like machines in Star Trek's multi-ethnic universe. But unlike machines, humans are neither "made" nor "artificial." Thus, their distinctive feature in comparison to machines is their ability to experience emotions, to act on genuine empathy for others and to possess a unique sense of humor. This difference between humans and machines is first laid out in The Next Generation by the android Data and his attempts to become more human; this role is taken over in Deep Space Nine by the shape shifter Odo. In Voyager it is the holographic doctor and eventually also the former Borg drone Seven of Nine who strive toward a "proper" human existence shaped by emotion, empathy, and humor.

On the y-axis the category "Human" is defined by the Federation and Starfleet's humanist values. They are the necessary requirements of a democratic society held together by abiding laws which guarantee the continuance of these values. They determine the use of technology as indicated by the y-axis' poles: either technology is used according to these humanist values in a "good" or peaceful way that is beneficial 
to others and altruistic, or, contrarily, in a "bad" or hostile way that is aggressive and egotistic. This differentiation in the use of technology corresponds to posthuman perspective in which technology, or more precisely its use as prosthetic refinement is considered an improvement of the human body and its physical as well as mental shortcomings. In Star Trek's multi-ethnic universe, the Borg represent a dystopian vision of this posthuman perspective. Consequently, this cyborg race is located in the far lower right-hand corner of the coordinate system: on the one hand the Borg are humanoid beings equipped with mechanical parts (allocation on the x-axis), and on the other they use their technological superiority to mercilessly assimilate other life-forms into their collective. Hence, the Borg can be considered a hostile race (allocation on the $y$-axis).

16 All alien races presented in Voyager can be charted in the coordinate system as described above. The Caretaker, for instance, is a non-human entity who uses his advanced technology to protect the pacific Ocampans from attacks by the aggressive Kazons. Despite its altruistic intentions, the Caretaker does not hesitate to capture members of other alien races from all over the galaxy against their will (and without means for them to return) in order to find a suitable mate. As the last survivor of a dying species, the Caretaker is desperately trying to procreate, leading to Voyager and its crew being translocated to the Delta Quadrant, a region of the galaxy uncharted by Starfleet and the Federation (cf. Voyager S01/E01). On the journey home, Voyager encounters many unknown races, for example on several occasions the Hierogens. Soon the crew become the prey of this race of nomadic hunters. At one point the Hierogens are successful in their attempt to conquer the ship in order to use its superior holographic technology: a Hierogen leader wants to unite his people by setting an end to their scattered existence. He forces Voyager's crew to partake in a simulation of the Hierogens' hunt on the ship's holodeck in a World War II setting where the Hierogens play the role of Nazis. Captain Janeway and her officers can finally take back control of the ship and negotiate peace with their captors by offering to help them recreate the holodeck technology and subsequently adapt it for the Hierogens' purposes (cf. Voyager S04/E18, S04/E19).

In the following I will discuss the use of technology by two allegedly hostile races in more detail: the Vidiians and the Borg. ${ }^{2}$ Even though both races are egocentric in their use of advanced technology their intentions during their numerous encounters with Voyager are ambivalent. Their behavior and interactions with Voyager's crew call into question both Starfleet and the Federation's humanist values in regard to the altruistic use of technology as well as the supposed monstrosity of these non-humans.

\section{Alien Monstrosity I: The Vidiians, or Hidden Humanity}

18 As Voyager moves through the "unexplored territory" (Roberts 204) of the Delta Quadrant, this galactic Frontier provokes new encounters with unknown others, while the crew itself mirrors the multi-ethnic Federation through "a multicultural ensemble cast" (Kwan 65). With its wide range of characters the series not only "reflects the complex and contradictory expressions of race in the 1990s" (Roberts 205), but also calls into question the "speciesist logic of domination" (Rossini 155) implicitly connected to the centuries old humanist tradition embodied by Starfleet and the 
Federation. In the context of $18^{\text {th }}$ century humanism, being human means, as Manuela Rossini explains, "not only not to be a 'beast' but also to subscribe to a specific code of humanity, a code that has essentialized differences of ethnicity and race, class, gender, and sexuality" (155). Over the course of history "these 'natural' differences... helped to build hierarchical systems of domination as well as taxonomies of the human/ inhuman/nonhuman that for centuries have legitimated... the oppression, torturing, eating, and killing of beings not falling into the category "human"' (Rossini 155). By visualizing alien races through their specific use of technology, Voyager calls into question what Rossini calls a "code of humanity" with its essentialized differences and values. Even though the aliens' use of technology seems hostile at the onset, their motives and intentions eventually become more ambivalent when set against Starfleet and the Federation's specific "code of humanity" which prohibits such specific use of technology in a 'bad' way towards others. The depiction of two alien races presented in two major storylines in Voyager illustrates this ambivalence: although both the Vidiians and the Borg are generally hostile and therefore similar in their use of technology, they are on opposing sides of the axis of otherness in the coordinate system presented above.

19 The aliens in science fiction are akin to the monsters of the horror genre; they are 'semiotic bodies' (cf. Jablonski167ff.), and at the same time "a construction and a projection" (Cohen 4). According to Jeffrey Jerome Cohen, monsters can be understood as the universal signifier of otherness and therefore as the embodiment of human anxiety and xenophobia (cf. Cohen 14f.). "In science fiction stories, the monster always played a starring role, ever since the birth of the literary genre itself" (Gramantieri 287). Riccardo Gramantieri thus argues that "the term monster is almost synonymous with science fiction" because monstrosity has always been associated with "deformity" and "alienness" in regard to human physiognomy (287f.). Therefore, the monstrous "artificial creatures" in science fiction are a mere "technological variant of aliens" (Gramantieri 289). As Graham points out, "[o]ne of the ways in particular in which the boundaries between human and almost-human have been asserted" in SF literature, film, and television has always been "through the discourse of "monstrosity" (12). Aliens and monsters function alike as the latter usually also "serve both to mark the fault-lines but also, subversively, to signal the fragility of such boundaries" between the human and the non-human (Graham 12). In Voyager the monstrosity of the series' aliens is conveyed by the depiction of their use of technology.

The Vidiian storyline begins in the first season: during an away mission, Voyager's moral officer Neelix, a Talaxian who is indigenous to the Delta Quadrant and has found refuge aboard the starship (cf. Voyager S01/E01), is attacked by an unknown alien (cf. Voyager S01/E04), who, as it turns out, has removed Neelix's respiratory organs. The only way for Neelix to survive depends on the holographic doctor's creative use of technology: he manages to create holographic lungs, but these artificial organs require that Neelix be immobilized in sickbay until a transplant can be organized. With no suitable donor among Voyager's crew, the only option for Captain Janeway is to find the alien attacker and retrieve the organs. Neelix's tricorder-a mobile technical device used by the crew to gather all kinds of information-offers a few clues. The Captain is informed that the tricorder's "bio-scanner picked up a single class-three humanoid organism" leading Janeway to go with "an away team back to the planet" in order to find the alien. 


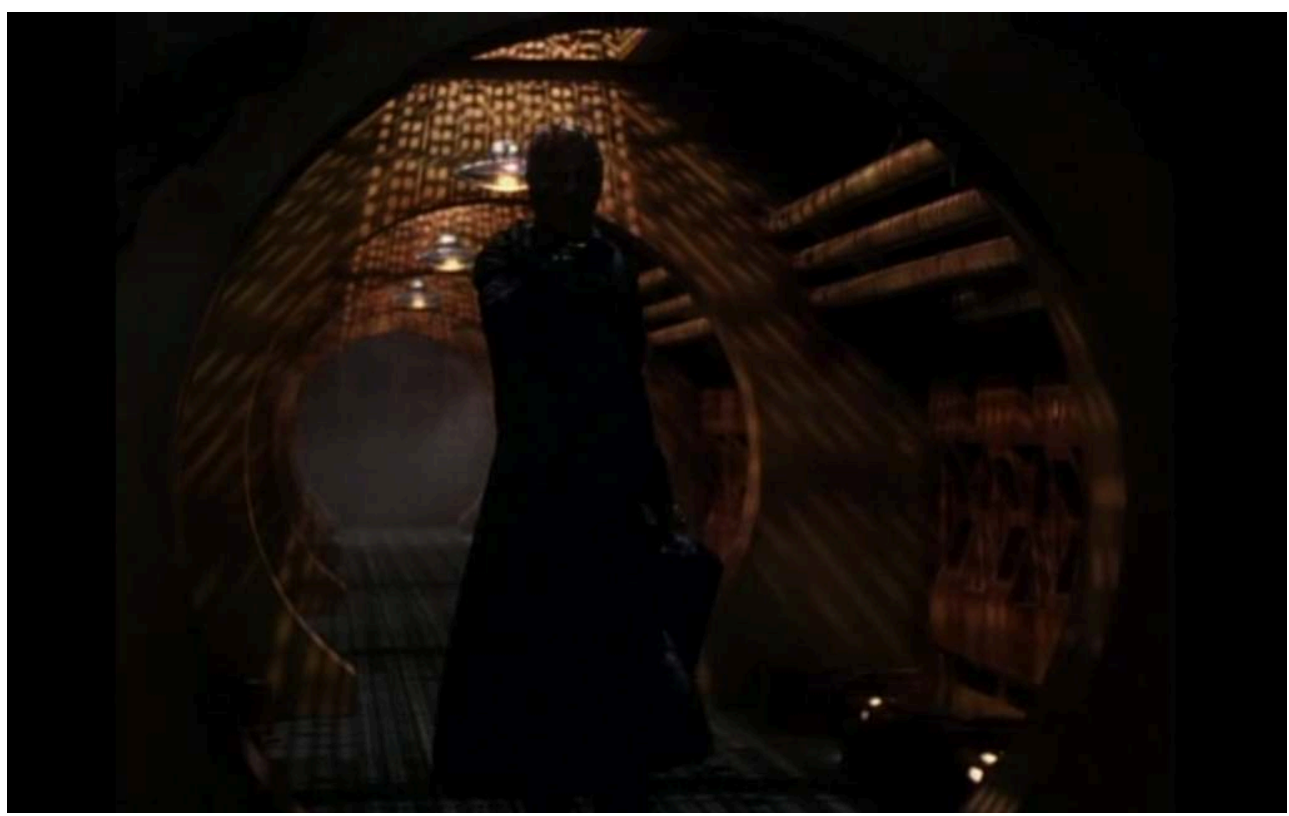

Figure 2: Voyager S01/E04, 00:08:26.

The episode begins on an away mission and the viewer quickly gets a few glimpses of the alien who we later learn is Vidiian (cf. Voyager S01/E04). The first depiction is a medium long shot showing a dark, humanoid-shaped silhouette in a dimly-lid tubular corridor (Fig. 2). The lighting and the monochromatic brown and grey colors generate a sense of foreboding as the alien sneaks up on Neelix and fires a laser weapon at him. This is shown in a medium shot from a straight-on angle: Neelix stands in the foreground on the left with his back turned and the alien is positioned a bit further left with his face half in shadow (Fig. 3). The first shot grants no view of the alien's face and the second only a partial one. As the initial image of the alien reveals little of his face and nothing of his intention, this opening sequence sets up a mystery that Captain Janeway will eventually solve.

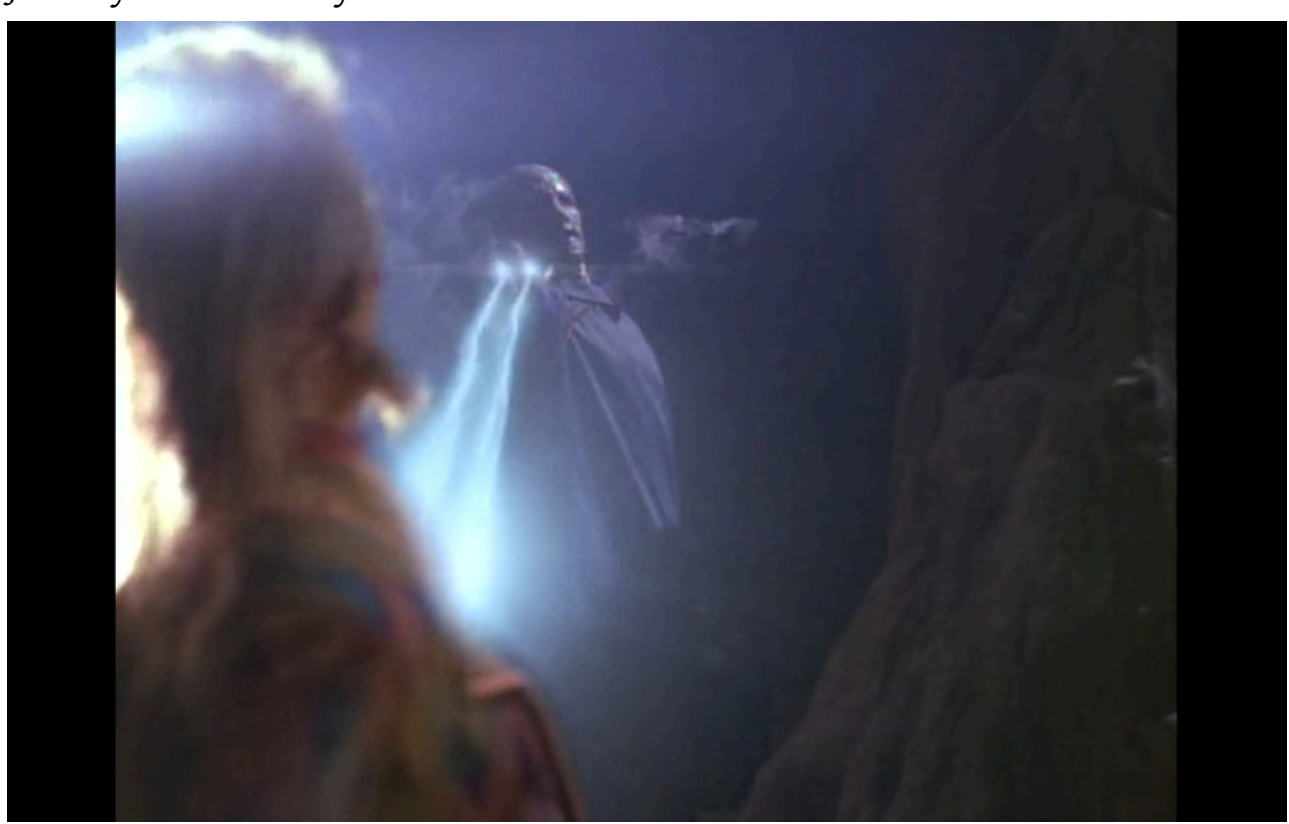

Figure 3: Voyager S01/E04, 00:09:02. 
When the Captain and an away team later return to the planet, they find a "biological repository," a place where all kinds of organs-obviously retrieved from a variety of other species both known and unknown to the Starfleet crew-are stored. An attempt to capture the alien fails and he subsequently escapes from the planet in a starship. The only new clue the away team can secure is the 'weapon' that was used by the alien. After further analysis aboard Voyager the crew learns that "it appears to be more than a weapon;" the device reveals itself to be "a very sophisticated medical scanner and surgical instrument" that had removed Neelix's lungs simply by firing at him. Janeway summarizes these findings, laying out the next mystery to be solved: "So it sounds like we're dealing with aliens who have developed a technology specifically designed to locate and extract organs from other beings. Why?" The crew pursues the alien's ship which is "evenly matched for speed" with Voyager. This last clue indicates that the alien and its race are technologically equal if not superior to Starfleet.

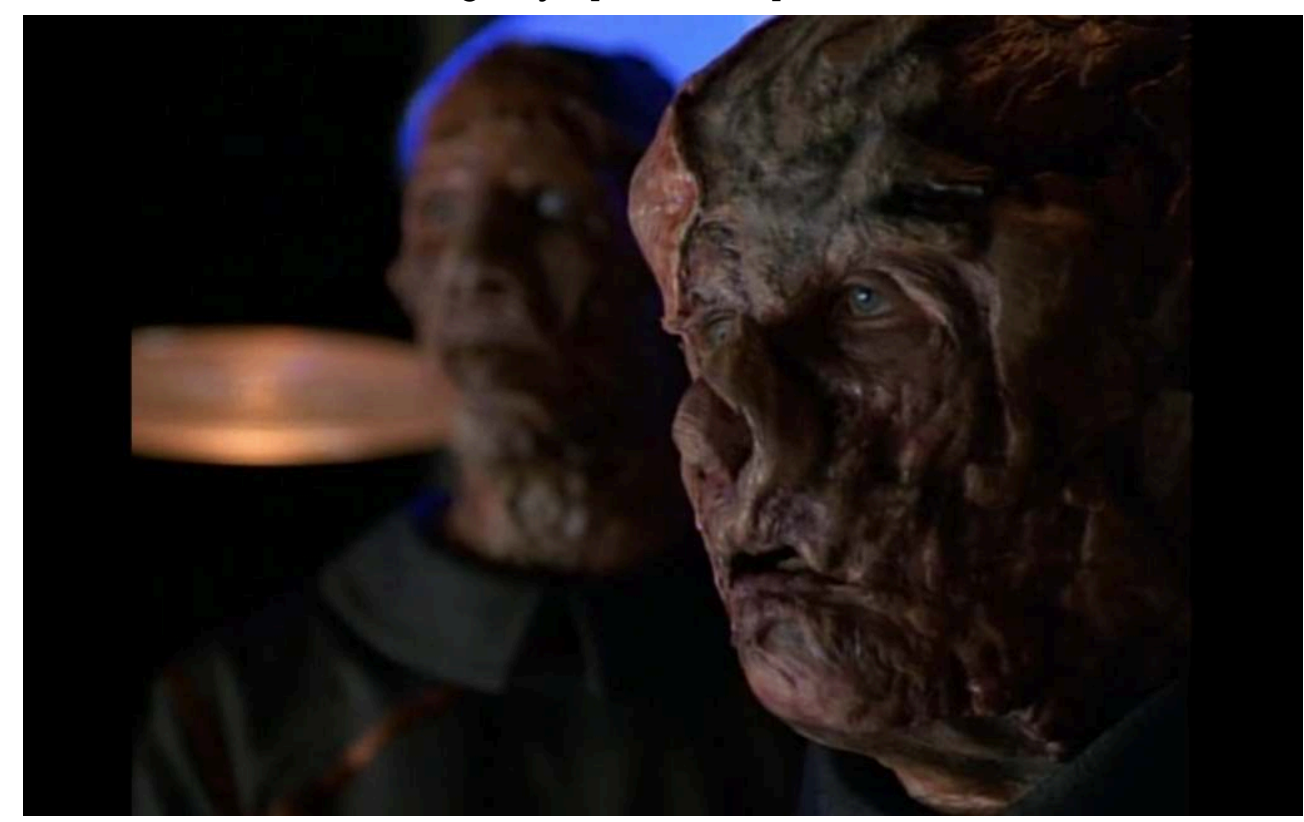

Figure 4: Voyager S01/E04, 00:35:11.

The Voyager crew locates the alien ship at a remote asteroid; they come up with a means to penetrate the ship's shielding and to beam aboard two of the unknown humanoids. This moment of revelation is depicted accordingly by showing the aliens' faces clearly for the first time (Fig. 4). The shot uses depth perception to reveal the aliens. The first face is in the background out of focus, the other, however, is in the foreground clearly in focus; and the positioning of these faces follows the order of reading illustrating the step by step revelation of the aliens. This revelation begins to resolve the episode's narrative intrigue because the initial presentation of the alien during the attack lacked one detail: the face. With its veiled depiction at the beginning of the episode the alien's face became the signifier of the mystery about its identity, motives, and intentions.

These are, in fact, revealed in the following dialogue between Janeway and the aliens. Furthermore, the dialogue shows how the aliens' depiction is determined by their motives for the attack on Neelix. During a brief interrogation, the aliens introduce themselves as Vidiians and they explain the fate of their race: for more than two hundred years the Vidiians, who are indigenous to the Delta Quadrant, have suffered 
from a viral disease called the Phage which consumes and decomposes their bodies. That is why they "are gathering replacement organs and suitable biomatter" by force from other life-forms. With their society ravaged by the Phage and thousands of their people dying each day, the Vidiians have developed special technology to deal with this disastrous situation by preying on other life-forms in order to harvest their body parts. It would seem that this alien race should be allocated near the left pole on the axis of otherness in the coordinate system described above: they appear more animal-like because they have succumbed to basic instincts in order to survive. Although Janeway expresses her humanist sympathy for the Vidiians, she makes it clear that those hostile actions cannot be tolerated. But since Neelix's organs have already been "biochemically altered" to Vidiian physiology and transplanted into one of the aliens it is no longer possible to retrieve his lungs.

The Vidiians try to justify their actions by explaining why they are willing to accept the lethal consequences of what they do to others in order to cope with the Phage. Thus, they appear less animal-like, and more human overall: "Our immunotechnology cannot keep up. The Phage adapts. It resists all attempts to destroy it.... There is no other way for us to survive." During this interrogation, the Vidiians are shown in close-ups the entire time in order to display the severe deformities of their heads and faces. The furrowed skin, countless prominent scars, and the different layers of subdermal tissue visible in their faces make them look zombie-like in comparison to their human counterparts whose faces are shown in medium close-ups. The Vidiians' motives and their techniques to stay alive are as monstrous as their outer appearance: although they try to extract the needed organs mainly from the dead, sometimes, "when the need is immediate, more aggressive actions are required." The use of such euphemistic rephrasing of their aggressive and hostile actions towards other life-forms is indicative of an intellectual capacity that is a reminder of this race's former civilized state: "Before the Phage began we were known as educators and explorers, a people whose greatest achievements were artistic." Here the metaphoric function of aliens in SF becomes obvious since the Vidiians' depiction of their civilization seems much more akin to the enlightened multi-ethnic culture of the Federation. Thus, this episode of Voyager entertains the dystopic thought of what might happen to humanity were it faced with a threat similar to the Phage.

Despite their horrifying appearance, the Vidiians' monstrosity lies in their use of technology. With virtually no remorse, they murder others for their own welfare. Such behavior contradicts Starfleet and the Federation's humanist values which are paraphrased by Janeway when she points out the ethical dilemma she is now facing-but the practice of these values is not always so obvious:

I can't begin to understand what your people have gone through. You may have found a way to ignore the moral implications of what you're doing, but I have no such luxury. I don't have the freedom to kill you to save another. My culture finds that to be a reprehensible and entirely unacceptable act. If we were closer to home, I would lock you up and turn you over to my authorities for trial. But I don't even have that ability here and I am not prepared to carry you forever in our brig. So I see no other alternative but to let you go.

Janeway takes the moral high road and her ethical superiority over the Vidiians is conveyed through cinematography in this scene: Janeway's face is constantly shown in medium close-up shots from a low angle as if from the perspective of the Vidiians. They 
are sitting on a step of the transporter platform throughout this scene and have to look up to Janeway standing in front of them.

The aliens seem to be moved by Janeway's display of mercy and her decision to free them, so one of the Vidiians offers to help in an unexpected way because their "medical technologies may be superior." When brought to see Neelix in sickbay, the Vidiians are presented on an eye-to-eye level with Voyager's crew members. This indicates that the Vidiians no longer pose a threat since they are now willing to use their advanced technology for the benefit of others. Thus, the depiction now grants them the status of true "humans," which means that the humanist values Janeway presented before are now depicted as trans-racial and therefore universal. The Vidiians who find the improvised holographic lungs to be "primitive"-at least according to their high standards of medical technology-can, in fact, help Neelix. The Vidiian storyline continues in the second season of the series after one further encounter with the aliens who capture Voyager's chief engineer B'Elanna in order to extract her Klingon DNA in the hope of finding a cure for the Phage (cf. Voyager S01/E14).

In "Lifesigns" (cf. Voyager S02/E19), Voyager rescues female Vidiian doctor Denara Pel. Due to serious brain damage she has to be put into a coma. In order to communicate with her, Voyager's holographic doctor transfers her brain functions into the ship's computer and projects them into a holographic body. This is created according to the Vidiian woman's original DNA, thus showing the alien body without the Phage's mutilations. Obviously, this episode takes up the idea laid out in the Neelix-episode from season one by visually displaying the "human" side of the monster. In this latest encounter it is Voyager's technology which is beneficial to the Vidiians and, ironically enough, its use helps the alien to overcome the alienation from its true outer and inner self. After gaining consciousness in her new holographic body and seeing her unravaged face again after decades, Denara is emotionally moved. Under tears the says: “I... never expected to look healthy again. I've been sick for so long.... I never thought I'd see myself again.... This is the most extraordinary thing anyone has ever done for me." The act of kindness is repaid later, long after Voyager's doctor has repaired Denara's brain damage so that she can return to her people in her real body: when Captain Janeway and Commander Chakotay have been infected with a highly contagious sickness incurable by the doctor, he contacts Denara who can provide an anti-viral serum to save them (cf. Voyager S02/E25). Once more the Vidiians' advanced medical technology is used to benefit others. Thus, the aliens' outward monstrosity fades when they offer charity through the use of technology.

\section{Alien Monstrosity II: The Borg, or Family Matters}

As machine/life-form synthesis, the Borg are situated on the machine pole of the axis of otherness in the coordinate system described above. As all other "technologized, artificial and cyborged life-forms in the Star Trek universe," these hostile aliens "serve as... inversions or refractions of 'our' exemplary and normative humanity;" the Borg "stand for the ultimate threat to the Star Trek vision of human progress and individual integrity" (Graham 133). They are, in fact, a version of the "posthuman body" which is "a prosthetic body" equipped with technologically extended or replaced extremities as well as enhanced mental capacities through artificial intelligence (Gramantieri 293). Those beings created by "fusions of the organic and cybernetic" are called "cyborgs" 
(Graham 3); according to Gramantieri, the cyborg "is the contemporary "monster" because it is "a creature that simulates man" (303). Due to their "corruptions of the ontological hygiene of the body... achieved by means of invasive technological implants" (Graham 133), the Borg do not merely simulate man, they transgress him. As a collective with a shared consciousness they are the opposite of any society based on the principles of individuality and democracy. Thus, they are Star Trek's political metaphor for totalitarian regimes.

31 Furthermore, the Borg represent a perversion of humanity according to the humanist values of Starfleet and the Federation: they do not learn through experience or gain knowledge through individual thought in order to progress culturally. Instead, the Borg "assimilate," meaning they force others, who lose all sense of self, into their collective. Thus, in this case "[a]ssimilation is a euphemism for genocide" (Graham 145). By absorbing other life-forms' technological, physical, and cultural distinctiveness the Borg try to achieve a state of "perfection." Obviously, this ultimate goal is a perversion of what Jean-Jacques Rousseau describes as perfectabilite (142), the human capability to perfect oneself in order to abolish inequality and disparity among the individuals of a given society. But a society created according to Borg perfection sacrifices the individual. Their collective functions like a beehive: the drones, as a single Borg is referred to, have designated numbers instead of names and their actions are controlled by one queen. Due to this societal organization " $t]$ he Borg's gender and race identity is complicated" (Roberts 205). At the same time their posthuman gender and race is "in a sense hybrid" and that is why they pose a specific threat to Starfleet and the Federation's humanist values, as Roberts elaborates: "The Borg emphasize the construction of race because they literally construct other races as their own, a classic assimilation model. Because they form a collective, they represent a feminine mass that threatens Western notions of the individual, who is putatively masculine" (205). ${ }^{3}$

With a multi-ethnic crew under the command of a female captain, Voyager plays out two different possibilities for coping with unexpected challenges at the remote end of the galaxy "without being constrained by a white, male-dominated hierarchy such as Starfleet" (Roberts 204). One of these possibilities, unimaginable in the Alpha Quadrat, is a temporary alliance with the Borg. Janeway proposes a deal with them as she knows that the Borg are at war with an alien species from another dimension called fluidic space. These aliens, who are referred to by their Borg designation as species 8472, use biotechnology which is deadly to the otherwise invincible Borg and to their advanced cybernetic technology. Since they only acquire knowledge through assimilation, the Borg are not able to eradicate these new enemies as they cannot be assimilated. Herein lies Voyager's advantage as the crew is able to examine the aliens and develop a weapon against them. Janeway is willing to share this knowledge about species 8472 with the Borg in exchange for free passage through their space (cf. Voyager S03/E26, S04/E01).

This deal is made in the double episode "Scorpion" marking the transition from season three to four. Additionally, "Scorpion" marks an extraordinary moment in the entire story of Voyager: Seven of Nine, a Borg drone of human origin, is separated from the Collective and integrated into the crew, becoming a central character in the series. Due to the skills of Voyager's EMH, Seven's human appearance can be restored, but she still has a long way to go to adapt to human society (cf. Voyager S04/E02). Thus, the Seven of Nine storyline in Voyager is a variation of the topos first brought up with the Vidiians; 
here the monstrous Borg's human side is revealed. Furthermore, the series presents Seven's struggles with her newfound individuality as a reflection on humanity which "is not an innate property, but... a state of characteristics to be acquired amid a plethora of values and role models affirmed by one's own deeds in the thick of uncertain circumstances" (Graham 151). Generally, "Seven remains alien, not accepting her humanness" (Roberts 216) by referring to herself as Borg instead of human and by keeping her Borg designation instead of her birth name. Since Seven "was assimilated at an early age, she has few social skills and no human cultural knowledge" (Roberts 261). Thus, she often appears child-like in her behavior in certain social situations as well as in her perception of them. In fact, parallels are often drawn between Seven of Nine and Naomi Wildman, the first child born on Voyager four years before Seven's appearance. Both the child and the former Borg drone struggle to find their position and purpose in the ship's community.

This alignment of Seven and Naomi's storylines is of narrative significance from a posthumanist perspective: Donna Haraway points out that the cyborg, in a "humanist sense," "has no origin story" that depends "on the myth of original unity, fullness, bliss, and terror, represented by the phallic mother from whom all humans must separate" as their unique "task of individual development" (Haraway 151). In Voyager Seven "regains" such an origin story and therein lies the series' narrative purpose with her storyline. The idea of phallic motherhood is laid out in another double episode when Seven distances herself from the Captain as her new human "mother" by rejoining the Borg Collective to serve her cybernetic 'mother' the Borg Queen (cf. Voyager S05/E15, S05/E16). As it turns out, Seven had been blackmailed by the Queen into returning to the Collective, and she only cooperated with the Borg in order to save Voyager. When the Borg Queen first appears, the depiction envisions her as phallic mother: after Seven passes through a vulva-shaped automated door to enter the "throne room" a cylindric tube descends from the ceiling. The tube holds the Queen's bust which is put into an assembling body. The phallic connection between bust and body is made by a tail-like wagging spinal column. This mechanical "act" is presented through a straight on medium shot (Fig. 5). Visually, this scene subverts the process of human and therefore bodily conception. ${ }^{4}$

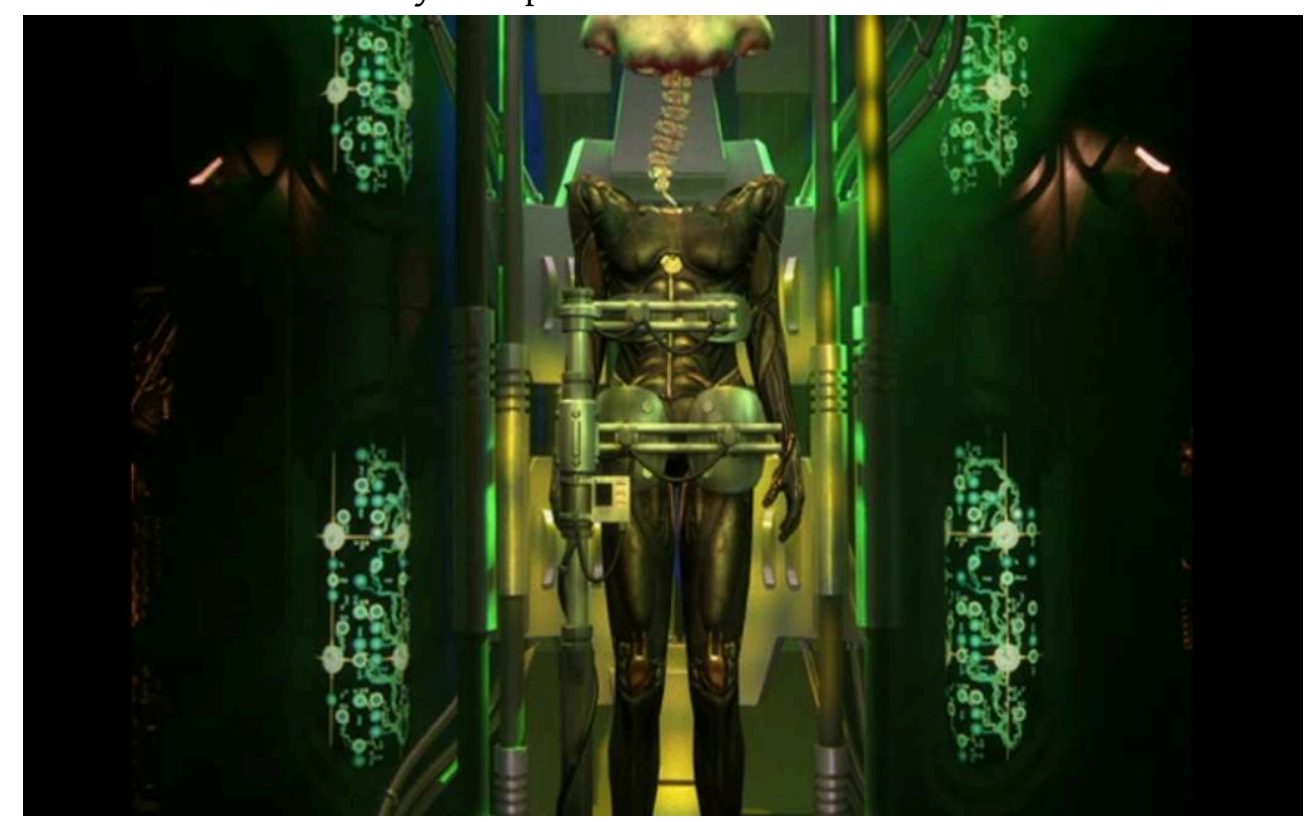


Figure 5: Voyager S05/E15, 00:42:57.

After the Queen has welcomed Seven back "home," she reveals that Seven's earlier liberation from the Collective was not by chance, indeed, it was part of the Borg's plan all along to use her in order to assimilate humanity. In this plan, Seven is assigned a "prosthetic" function:

You believe that Voyager liberated you from the Collective. Did you really think we would surrender you so easily?.... Don't be afraid. We won't turn you into a drone. You're much too valuable to us with your individuality intact.... They've corrupted you, but the damage can be repaired.... You're going to help us assimilate humanity. We failed in our first attempt to assimilate Earth, ${ }^{5}$ and we won't succeed the next time unless we understand the nature of their resistance. We want you to be our eyes. Let us see humanity.... You are the only Borg that has ever returned to a state of individuality. We want to keep you exactly the way you are. Otherwise, you would lose your human perspective. We don't want another drone. We want you.

The Queen's plan fails because Captain Janeway can rescue her "daughter." The relations among Voyager's crew members are-far from strictly professional-in fact, familial. Throughout the series Janeway refers to the community aboard her vessel as "family." Both family and society are reflected upon in Voyager as concepts of community. Interestingly, these concepts are explored in relation to the Borg Collective in two episodes that portray communal structures which are created through the subversive use of Borg technology (cf. Voyager S03/E17, S06/E02).

Even though the Borg's hostility has been commonplace in the Star Trek universe ever since the Collective's first appearance in the franchise, Voyager entertains the idea that the Borg's monstrosity is at times ambiguous-long before Seven has joined the crew. When Commander Chakotay investigates a distress call from a lonely planet he encounters a group of drones whose link to the Collective has been severed after their ship was damaged by a stellar phenomenon (cf. Voyager S03/E17). Having regained their individuality these former drones want to build a new society, but their community is falling apart due to racial separation. They need Voyager's help in order to reactivate their former Borg neurotransceivers and unify their people. The female leader of the group discusses this possibility: "We've given it a great deal of thought, and we believe the solution to our problem is to reestablish the neural link among all the former Borg living on the planet.... If you think about it, Captain, when we were linked, we had no ethnic conflict. There was no crime, no hunger, no health problems. We lived as one harmonious family." What sounds like a utopian society much like the Federation's self-stylization, is, in fact, achieved by a totalitarian use of technology, as Janeway points out in reply to this request for assistance: "With all due respect, Dr. Frazier, you were 'one harmonious family' bent on the violent assimilation of innocent cultures." Yet it seems as if this newly formed collective, which calls itself "Cooperative," could make use of the Borg's technology in a benign way with no hostile intentions: "But we're not Borg anymore, and we've learned from our past. All we want to do is to take the one good thing that existed in the midst of all the horror: our unique ability to cooperate and problem-solve and use it to create a safe and productive community."

Although the Cooperative's intentions seem to follow the same humanist values represented by Starfleet and the Federation, Janeway refuses to give Voyager's technological support to the former Borg's undertaking because, as she says, "[n]ot only would it mean imposing a choice on thousands of people who had no voice in the decision, but it would also be taking a terrible risk" to help create a new collective 
without knowing the possible repercussions. Whereas Janeway ambivalently expresses her admiration and respect for the plan proposed by the former Borg, the first officer feels genuine sympathy for them. During the away mission Chakotay had been wounded and because there was no contact with Voyager the former drones treated his head injury by temporarily integrating his conscious into their limited collective. This, as one drone explains, not only creates a shared conscious but also "has inherent medical applications" due to "a continuous neuroelectric field" capable of regenerating any damage of organic tissue. Chakotay describes his experience to the Captain: "I heard their thoughts, felt their feelings, saw through their eyes."

Ironically, the Borg's technology is usually perceived as inhuman, but in this case its use not only benefitted Chakotay, it helped him to broaden his humanitarian perspective by enhancing his genuinely human empathy. Even though Chakotay's link with the former drones was severed after his injuries healed, the connection is still accessible to the former Borg. They gain control over his mind again and use the first officer to circumvent Janeway's refusal to help them. Through Chakotay, the former Borg use Voyager's technology to reestablish the neural link among all drones and reinstate a new collective on their planet. This episode ends with a certain ambivalence towards the use of technology. Since the outcome of the former drones' plan is not presented, one can only share Chakotay's doubts about whether "their ideals will last in the face of that kind of power."

The collective established by these former Borg drones creates a new society. But Borg technology can also be applied on a smaller scale creating familial groups as shown in the second episode of Voyager's sixth season. The narrative structure of "Survival Instinct" is complex because the plot shifts between two storylines, covering Voyager's present and the other Seven of Nine's past as a drone (cf. Voyager S06/E02). In the present, Seven encounters three former drones with whom she was once stranded on a lonely planet, where they began to regain their individual minds and remember their pasts as individuals. Seven, who had been assimilated as a child, does not possess such memories, and she forces the other drones back into a temporary collective until the real Collective can reintegrate them. But those actions from the past have lasting consequences: due to Seven's interference, the three drones' minds have been connected to each other ever since-even after they free themselves from the Borg a second time. Now they need Seven to sever this link among them. Although the procedure to accomplish this puts Seven at risk, she "feel[s] compelled to help them," as she admits to Janeway. In her role as "mother," the Captain tries to fathom Seven's true motives by asking whether she thinks "of these people as family." The Captain's question shows Seven that family is not a matter of biology but social relations. Intrigued by this idea and in lack of any real biological relatives, Seven examines her relations in the community of Voyager's crew looking for familial structures. For example, she engages in a brief conversation with her child "equivalent":

Seven of Nine: Naomi Wildman, do you consider me to be family?

Naomi: I... I don't, I mean, well, yes. Is that okay?

S.: I have no objection.

N.: Do you think of me as family?

S.: Yes.

41 As soon as Seven's mind is linked with the three former Borg drones the two narrative storylines are synchronized. The viewer can identify the events previously depicted from Seven's past as flashbacks focalized through her: the moment Seven closes her 
eyes when linked to the other drones aboard Voyager in the present, a sequence of eleven shots-none lasting longer than a second-summarizes the events leading up to how she and the others become stranded on the planet. Since the events in this montage were depicted previously in the episode, the viewers can now easily identify them as a brief recapitulation of the story. This recap is cinematographically linked to Seven's perspective, as she is the originator of these recollected memories: after the short sequence ends, Seven's former Borg face is first presented in a medium close-up (Fig. 6), but then the camera rapidly zooms out broadening the entire frame of this shot showing all four drones standing in line linked together (Fig. 7). Consequently, the movement of the camera in this sequence of recollected events from the past visually conveys what is happening in the present: Seven of Nine has rejoined her old collective.

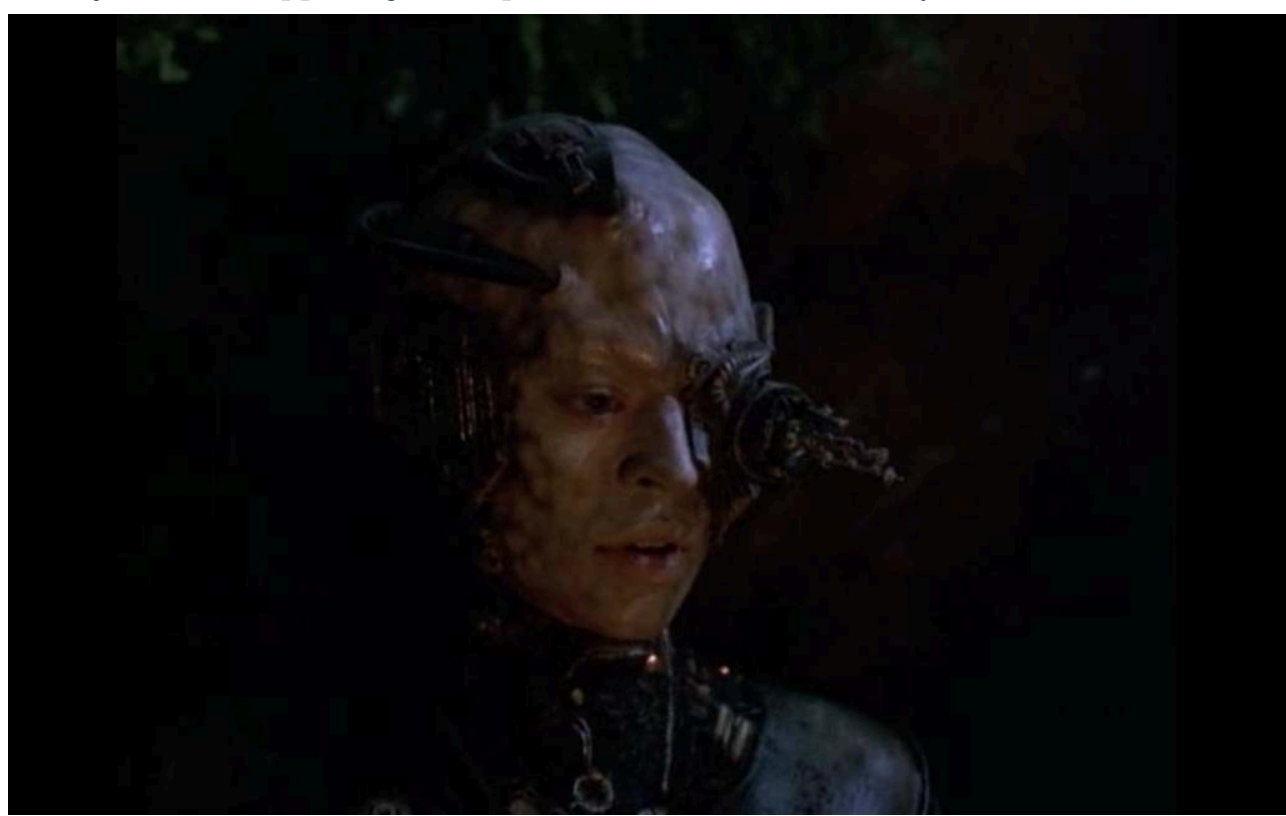

Figure 6: Voyager S06/E02, 00:28:40.

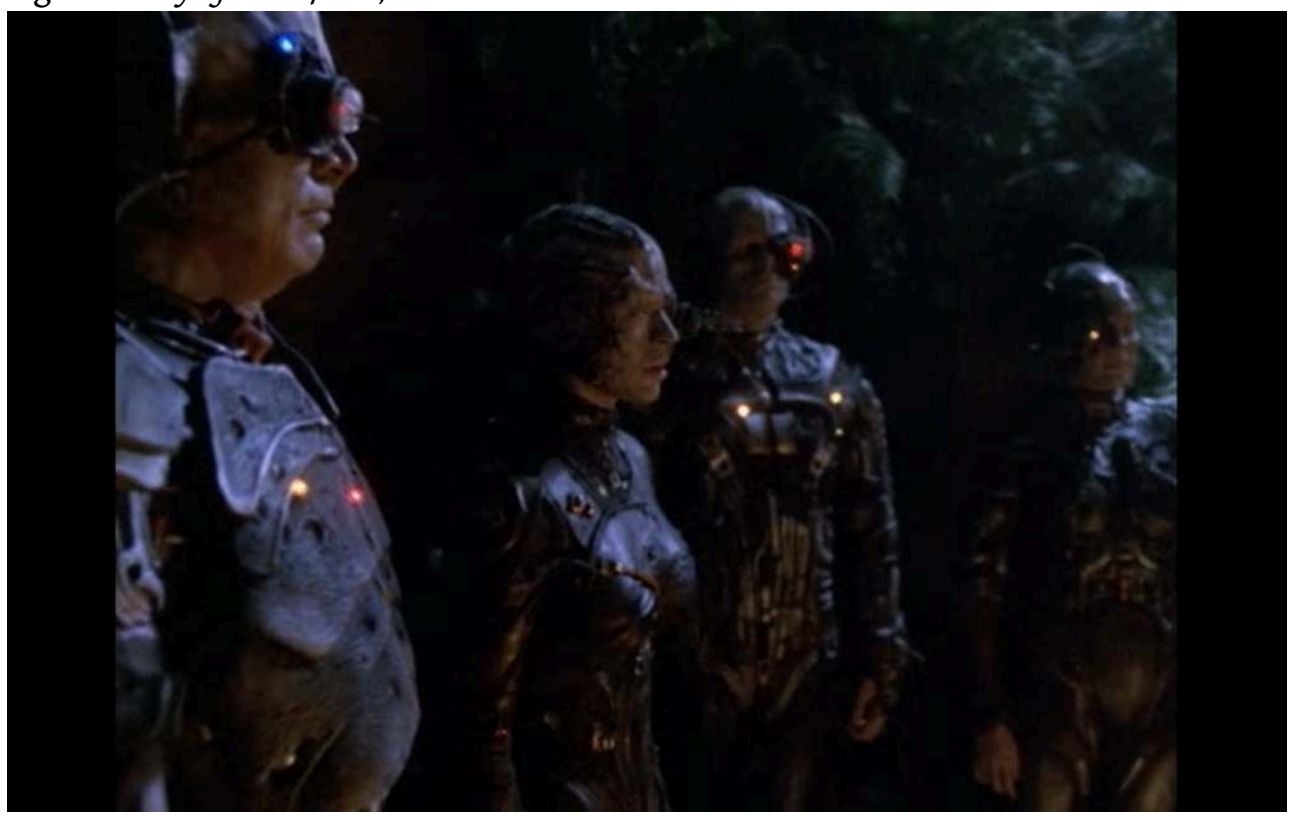

Figure 7: Voyager S06/E02, 00:28:43. 
Seven's reconnection with the others has been partially successful: the three former drones have fallen into a coma, but the doctor, who has monitored this procedure, now knows how to sever the connection. Yet, the prospect of freedom comes with a price: since their minds have gone into neural shock during the reconnection with Seven, reviving them now would reduce their life spans to a few weeks. The only alternative for them to survive would be re-assimilation into the Borg Collective. Since the former drones are, as the Captain calls them, Seven's "distant cousins," she has to make a decision about their future by weighing the benefits of using the Borg's technology: it would prolong their lives-but as drones not as individuals. Given her past and her obligation to them, Seven informs the doctor about her decision by explaining her motives: "Survival is insufficient.... Eight years ago, I forced them to return to the Collective. I won't make the same mistake again. They deserve to exist as individuals. We must terminate the link between them.... I simply want them to experience individuality as I have." Obviously, this episode negotiates the price of the ultimate humanist value: freedom, "no matter how fleeting" as Seven argues, is essential to any existence as an individual and therefore unalienable. Since it is such individuality the former drones have striven for, Seven decides in favor of their freedom rather than mere survival.

This episode shows how the Borg and their use of technology "undermine human integrity" (Graham 136). Throughout the series, the use of technology gives contour to this idea of integrity. The aliens in Voyager, as with "all television aliens" alike, "must be read as ciphers for humanity" (Roberts 207) in general. That is why alien races like the Borg or the Vidiians appear monstrous according to Starfleet and the Federation's humanist values: their otherness does not as much rely on physical differences as on the alternate use of technology. Though Roberts correctly says that in Voyager "race is depicted as being about culture and identity" (207), one must add that this specific depiction of race also depends on the use of technology either by aliens or humans. Furthermore, this use of technology is crucial to the series' specific depiction of the "constructedness" (Roberts 207) of race. Thus, race is not only a social but also a technological construct.

\section{BIBLIOGRAPHY}

“ethnic." Oxford Dictionary of English. Ed. Stevenson, Angus. Oxford University Press, 2010. Oxford Reference. Date Accessed 22 Jun. 2020 <https://www.oxfordreference.com/view/10.1093/ acref/9780199571123.001.0001/m_en_gb0275130>.

“ethnicity." Oxford Dictionary of English. Ed. Stevenson, Angus. Oxford University Press, 2010. Oxford Reference. Date Accessed 22 Jun. 2020 <https://www.oxfordreference.com/view/10.1093/ acref/9780199571123.001.0001/m_en_gb0275150>. 
"race." Oxford Dictionary of English. Ed. Stevenson, Angus. Oxford University Press, 2010. Oxford Reference. Date Accessed 22 Jun. 2020 <https://www.oxfordreference.com/view/10.1093/acref/ 9780199571123.001.0001/m_en_gb0682260>.

"species." Oxford Dictionary of English. Ed. Stevenson, Angus. Oxford University Press, 2010. Oxford Reference. Date Accessed 22 Jun. 2020 <https://www.oxfordreference.com/view/10.1093/ acref/9780199571123.001.0001/m_en_gb0797920>.

Balibar, Etienne. Masses, Classes, Ideas: Studies on Politics and Philosophy Before and After Marx. Routledge, 1994.

Bernardi, Daniel. "Star Trek in the 1960s: Liberal-Humanism and the Production of Race." ScienceFiction Studies, vol. 24, 1997, pp. 209-225.

Carrington, André M. Speculative Blackness: The Future of Race in Science Fiction. U of Minnesota P, 2016.

Cohen, Jeffrey Jerome. Monster Theory: Reading Culture. U of Minneapolis P, 1996.

Golumbia, David. "Black and White World: Race, Ideology, and Utopia in Triton and Star Trek." Cultural Critique, vol. 32, 1995/1996, pp. 75-95.

Graham, Elaine L. Representations of the Post/Human: Monsters, Aliens and Others in Popular Culture. Rutgers UP, 2002.

Gramantieri, Riccardo. “Artificial Monsters: Form Cyborg to Artificial Intelligence.” Monsters of Film, Fiction, and Fable: The Cultural Links between the Human and Inhuman, edited by L. Wenger Bro et al., Cambridge Scholars Publishing, 2019, pp. 287-313.

Haney II, William S. Cyberculture, Cyborgs and Science Fiction: Consciousness and the Posthuman. Rodopi, 2006.

Jablonski, Nils. “Deconstructing Dracula: The Vampire as Semiotic Body in Stephenie Meyer's Twilight." Transitions and Dissolving Boundaries in the Fantastic, edited by C. Lötscher et al., Lit, 2014, pp. 167-178.

Jameson, Fredric. Archeologies of the Future: The Desire Called Utopia and Other Science Fictions. Verso, 2005.

Kwan, Allen. "Seeking New Civilizations: Race Normativity in the Star Trek Franchise." Bulletin of Science, Technology \& Society, vol. 27, no. 1, 2007, pp. 59-70.

Nama, Adilifu. Black Space: Imagining Race in Science Fiction Film. U of Texas P, 2008.

Neuwirth, Manuela. “'Absolute Alterity'? The Alien Animal, the Human Alien, and the Limits of Posthumanism in Star Trek." European Journal of American Studies, vol. 13, no. 1, 2018, https:// journals.openedition.org/ejas/12464. Accessed 1 Feb. 2021.

Nieden, Andrea zur. GeBorgte Identität. Star Trek als kulturindustrielle Selbstversicherung des technisierten Subjekts. ça ira, 2003.

Pounds, Michael C. Race in Space: The Representation of Ethnicity in Star Trek and Star Trek: The Next Generation. Scarecrow P, 1999.

Roberts, Robin A. "Science, Race, and Gender in Star Trek: Voyager." Fantasy Girls: Gender in the New Universe of Science Fiction and Fantasy Television, edited by E. R. Helford, Rowman \& Littlefield, 2000, pp. 203-221.

Rossini, Manuela. "Bodies." The Cambridge Companion to Literature and the Posthuman, edited by B. Clarke et al., Cambridge UP, 2017, pp. 143-169. 
Rousseau, Jean-Jacques. "Discours sur l'origine et les fondemens de l'inégalité parmi les hommes." Euvres complètes III, edited by B. Gagnebin et al., Éditions Gallimard, 1964, pp. 109-223. Star Trek: First Contact, USA 1998, Dir. Jonathan Frakes, Paramount. DVD.

Star Trek: Voyager, S01/E01: “Caretaker” (USA: January 16, 1995), Dir. Winrich Kolbe, Paramount. DVD.

Star Trek: Voyager, S01/E04: “Phage” (USA: February 6, 1995), Dir. Winrich Kolbe, Paramount. DVD. Star Trek: Voyager, S01/E09: “Prime Factors" (USA: March 20, 1995), Dir. Les Landau, Paramount. DVD.

Star Trek: Voyager, S01/E10: "State of Flux" (USA: April 10, 1995), Dir. Robert Scheerer, Paramount. DVD.

Star Trek: Voyager, S01/E14: "Faces” (USA: May 8, 1995), Dir. Winrich Kolbe, Paramount. DVD.

Star Trek: Voyager, S01/E15: “Learning Curve” (USA: May 22, 1995), Dir. David Livingston, Paramount. DVD.

Star Trek: Voyager, S02/E04: "Elogium" (USA: September 18, 1995), Dir. Winrich Kolbe, Paramount. DVD.

Star Trek: Voyager, S02/E11: “Maneuvers" (USA: November 20, 1995), Dir. David Livingston, Paramount. DVD.

Star Trek: Voyager, S02/E19: "Lifesigns" (USA: February 26, 1996), Dir. Cliff Bole, Paramount. DVD. Star Trek: Voyager, S02/E25: “Resolutions” (USA: May 13, 1996), Dir. Alexander Singer, Paramount. DVD.

Star Trek: Voyager, S02/E26: “Basics: Part I" (USA: May 20, 1996), Dir. Winrich Kolbe, Paramount. DVD.

Star Trek: Voyager, S03/E01: “Basics: Part II” (USA: September 4, 1996), Dir. Winrich Kolbe, Paramount. DVD.

Star Trek: Voyager, S03/E17: “Unity” (USA: February 12, 1997), Dir. Robert Duncan McNeill, Paramount. DVD.

Star Trek: Voyager, S03/E26: “Scorpion: Part I” (USA: May 21, 1997), Dir. David Livingston, Paramount. DVD.

Star Trek: Voyager, S04/E01: “Scorpion: Part II” (USA: September 3, 1997), Dir. Winrich Kolbe, Paramount. DVD.

Star Trek: Voyager, S04/E02: “The Gift” (USA: September 10, 1997), Dir. Anson Williams, Paramount. DVD.

Star Trek: Voyager, S04/E18: “The Killing Game: Part I” (USA: March 4, 1998), Dir. David Livingston, Paramount. DVD.

Star Trek: Voyager, S04/E19: “The Killing Game: Part II” (USA: March 4, 1998), Dir. Victor Lobl, Paramount. DVD.

Star Trek: Voyager, S05/E15: "Dark Frontier: Part I" (USA: February 17, 1999), Dir. Cliff Bole, Paramount. DVD.

Star Trek: Voyager, S05/E16: “Dark Frontier: Part II” (USA: February 17, 1999), Dir. Terry Windell, Paramount. DVD. 
Star Trek: Voyager, S06/E02: “Survival Instinct” (USA: September 29, 1999), Dir. Terry Windell, Paramount. DVD.

Star Trek: Voyager, S07/E20: “Author, Author” (USA: April 18, 2001), Dir. David Livingston, Paramount. DVD.

Suvin, Darko. Metamorphosis of Science Fiction: On the Poetics and History of a Literary Genre. Yale UP, 1979.

\section{NOTES}

1. The franchise includes seven major television series: Star Trek (1966-1969), Star Trek: The Next Generation (1987-1994), Star Trek: Deep Space Nine (1993-1999), Star Trek: Voyager (1995-2001), Star Trek: Enterprise (2001-2005), Star Trek: Discovery (2017-), and Star Trek: Picard (2020-). In addition, there are thirteen motion pictures, one cartoon series, numerous comic-books, novels, and video games.

2. But it is not only hostile aliens that Voyager encounters in the Delta Quadrant: the Sikarians, for instance, are willing to share their advanced transporter technology in order to help the Voyager crew find a faster way home (cf. Voyager S01/E09). The Talaxians also prove themselves to be benevolent. After Voyager has been captured by a Kazon sect under the lead of Seska, a former Voyager crewmate, they provide military support (cf. Voyager S02/E26, S03/E01). Since Seska has turned out to be a genetically altered Cardassian operative who was sent to spy on Starfleet, interstellar conflicts from the Alpha Quadrant extend into the other end of the galaxy (cf. Voyager S01/E10). Unlike Captain Janeway, who according to Starfleet's Prime Directive is prohibited from interfering with the politics of other alien races, Seska willfully helps the Kazons in their attempt to become a dominant force in the Delta Quadrant by stealing Voyager's advanced technology (cf. Voyager S02/E11).

3. It is not adequate to say that the Borg "construct" other races. Their aggressive "assimilation" implies a dismantling because the Borg eradicate virtually all traces of racial and cultural distinction as well as individuality. Thus, they do represent a mass, but this mass is hardly feminine. Roberts fails to describe what Andrea zur Nieden calls "Angst vor dem weiblichen Phallus" (97). It is the Borg's advanced technology which causes this "fear of the female phallus" because Starfleet and the Federation possess no means to outmatch it.

4. Although the Borg Queen appears female, this depiction symbolically combines features of both genders: the upper part of her body connotes "male" as it is depicted as the location of the mind, while the lower part is depicted as "passive," awaiting conception through coupling with the upper part. Thus, the depiction is logocentric. This scene quotes the Borg Queen's appearance in the franchise in the eighth Star Trek movie. In it, the Queen is initially depicted only by voice (cf. Star Trek: First Contact, 00:37:04ff.). This qualifies her as God-like because in the logocentric tradition God is thought of as a bodyless voice. When the Queen finally appears "in person," her Godliness is stressed even more: her first self-descriptive words are an indirect quote from the Bible's Book of Revelation as she refers to herself as "the beginning, the end" (cf. Star Trek: First Contact, 00:44:42f.).

5. The Borg Queen refers to events depicted in the Star Trek: The First Contact. 


\section{ABSTRACTS}

Alongside class, gender and age, race as an elementary category in modern science fiction is particularly apparent in the Star Trek franchise. The television series Star Trek: Voyager (USA 1995-2001) presents race as a cultural construct that depends on the specific depiction of technology and how it is used. This article analyzes several episodes of Voyager in order to explore how the series connects alien otherness with a certain practice of technology. It is this practice that determines the extent of the aliens' monstrosity; this practice either conforms with or deviates from the humanist values associated with technology and its use. Calling the universality of these values into question, the series presents a specifically posthuman depiction of race as technological construct.

\section{INDEX}

Keywords: critical race theory, cultural studies, cyborg, gender, genre, media studies, monster, otherness, posthumanism, race, science fiction, Star Trek, technology, television

\section{AUTHOR}

\section{NILS JABLONSKI}

Nils Jablonski is a post-doctoral scholar in literature and media studies employed at the University Hagen. He has published a book on media aesthetics of the idyll (Idylle. Eine medienästhetische Untersuchung des materialen Topos in Literatur, Film und Fernsehen, Berlin: J.B. Metzler 2019) and has also published on his further research topics such as humor, popular culture, interculturality and visual poetry. 